Vol. 7, No. 1, 2017

\title{
MACROMODELLING AS AN APROACH TO SHORT-TERM LOAD FORECASTING OF ELECTRIC POWER SYSTEM OBJECTS
}

\author{
Oksana Hoholyuk, Yuriy Kozak, Taras Nakonechnyy, Petro Stakhiv \\ Lviv Polytechnic National University, Ukraine \\ oph@polynet.lviv.ua,spg@polynet.lviv.ua,
}

(C) Hoholyuk O., Kozak Yu., Nakonechnyy T., Stakhiv P., 2017

Abstract: The paper is concerned with methods for the development of mathematical models intended for electric load forecasting, as well as an alternative method for the forecast of defined objects using discrete macromodels, which allows the quantative characteristics evaluation of future electric energy consumption to be analyzed using known previous data obtained during the field test. There is a description of the features of obtaining the experimental data and the procedure of developing discrete autonomous macromodels based on the data, using the "black box" approach in the form of state variables. A method for choosing the initial variables vector and the way of its introduction into the macromodel is developed because of the absence of an input variables vector in the explicit form. The expedience of applying the discrete autonomous macromodels for short-term electric load forecasting is shown. The developed mactomodel of daily power consumption of the power region served by an electric power substation for short-term electric load forecasting is presented, and the verification of the obtained results is carried out.

Key words: electric power system, macromodel, load forecasting, power consumption, optimization

\section{Introduction}

Forecasting the electric load provides main initial information for making decisions when controlling the power systems in the process of planning their normal electrical modes. All electric networks are characterized by permanent changes in load which can have daily, seasonal or occasional / sporadical character, in other words they depend on manufacturing requirements and can occur several times during a short-time period [4] that leads to a change in the quality of energy and the amount of its consumption over a period of time. In this regard, there are significant problems with ensuring the quality of electric power and the development of systems for load monitoring and forecasting.

Based on load forecasting, it is possible to calculate the initial and optimum modes of electric systems, evaluate their reliability, efficiency, quality of electric power, etc.
In spite of considerable amount of works dedicated to the electric load forecasting, the vast majority of them does not allow us to take into account the structure, specific features and technological peculiarities of electrical load, as well as the multilevel structure and the relationship between different types of power equipment, which leads to the necessity of developing a comprehensive approach to the solution of this problem [1-3].

Most of the algorithms intended for electric load forecasting are a combination of a variety of statistical procedures. There are procedures of electric load forecasting where separation to the basic component and the component responsible for load changes is needed. In addition, the methods where change in the electric load is considered as a random process can be used. However, adequate simulation is complicated due to nonlinear and complex relationships between loads(, factors which it depends on, and random influences. The fact that existing forecast procedures may not work with noise and incomplete data is also important, while the data available for simulation has exactly the same character. However, the electric load forecasting is based on taking into account certain known properties of the process. As it was noted, changes in the power system loading can have occasional, prababilistic character. The natural changes in the load and influence of stochastic factors lead to the absence of the strict periodicity in the load charts. Therefore, usage of some methods is the cause of the appearance of considerable errors in the estimation of the forecasted values, and the other methods due to the complicated mathematical apparatus have not been used widely for the solution of practical tasks of electric power engineering. Effectiveness of the available approaches can be verified in the way of estimating the least forecasting tolerance (accuracy), working ability of the algorithm under condition of insufficient information and its robustness.

Therefore, the development of new approaches, methods and algorithms for prediction of energy consumption, which would take into account the data of different kind and could consider inaccurate or incomplete data, is a relevant scientific and applied problem. 


\section{Models intended for electric load forecasting}

Load forecasting can be categorized into three main trends [7]:

1) long-term forecasting, used to predict the system state for decades;
2) medium-term forecasting, used to predict weekly, monthly and yearly peak loads up to ten years ahead;

3) short-term forecasting which is used to predict loads for one day up to a week ahead.

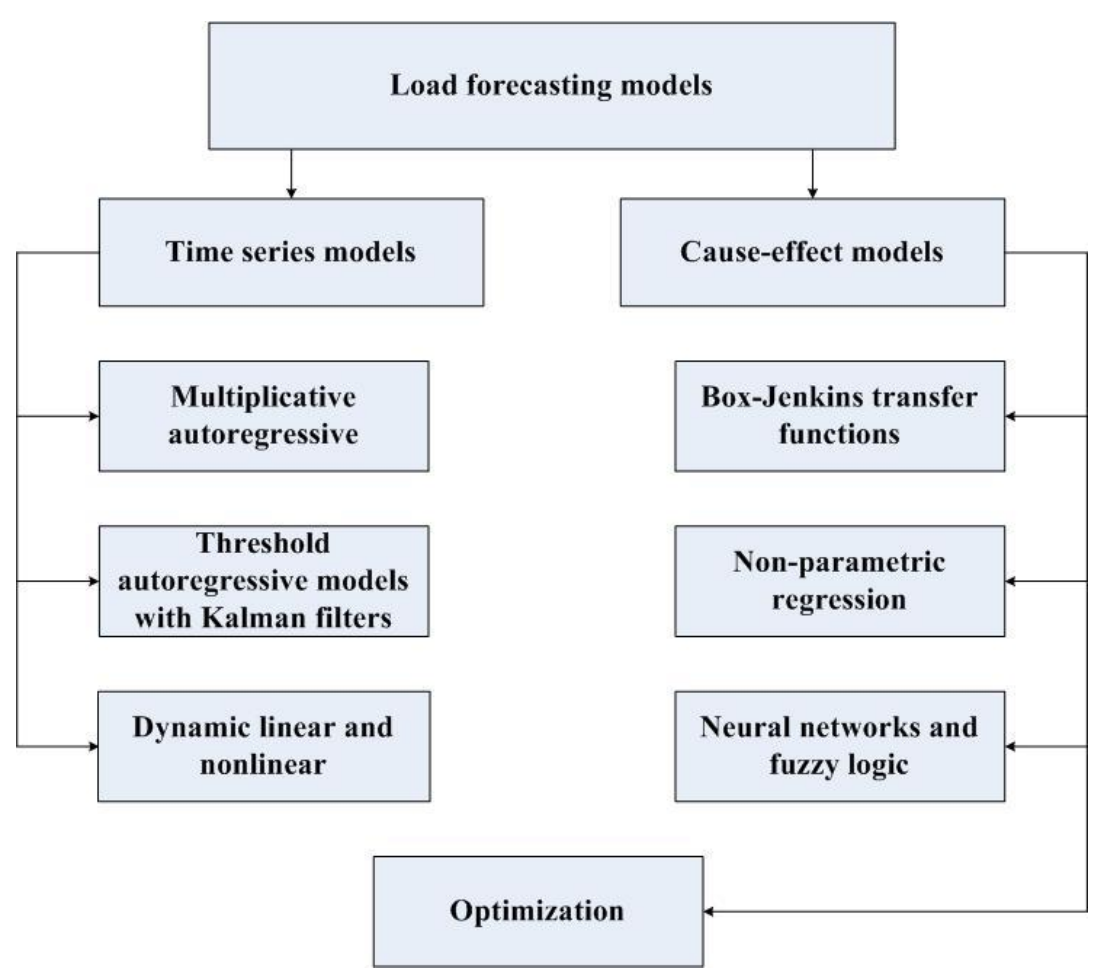

Fig. 1. Classification of models used for electric load forecasting.

The developed mathematical model for the load forecasting should represent in adequate mathematical form interrelations between energy consumption and factors influencing them (time, weather, economical factors, etc), therefore it is important to make a proper choice of suitable mathematical technique depending on the forecasting period.

Depending on the applied mathematical apparatus applied, models of electric load forecasting can represent and in the long term predict electric power consumption as a deterministic process or a process with a probabilistic character of electric power consumption. Therefore, mathematical methods can be divided into three groups: methods of analytical forecasting, methods of probabilistic forecasting and methods of statistical classification [2]

A general structural classification diagram of the models intended for solving this task is presented in Fig. 1.

Among the models developed for the electric load forecasting, the most widely used ones are:

1) Autoregressive models are time series models, in which the value of time series at some time moment is linearly dependent on the previous values of the same series. The autoregressive process of the order $p$ can be defined in the following way:

$$
X_{t}=c+\sum_{i=1}^{p} a_{i} X_{t-i}+\varepsilon_{t}
$$

where $a_{1}, \ldots, a_{p}$ are the parameters of the models (coefficients of autoregression), $c$ is some constant of the process (intended for simplification of the calculation process, frequently the value of this constant is considered equal to zero), and $\varepsilon_{t}$ is the white noise.

Using the autoregressive models makes it possible to simulate seasonal factors, and, in this case, the number of coefficients of the model will correspond to the number of cyclically changeable factors that are taken into account.

For the load to be forecasted, it is expedient to use the following form of an autoregressive model:

$$
L(t, d)=\sum_{k=1}^{4} a_{k} L_{k}(t, d),
$$

where $a_{k}$ are the linear weighted coefficients, which ensure the optimal combination of four separate 
forecasts, $L_{1}(t, d)$ is the forecast $L(t, d)$ on the basis of the first-order autoregressive model with one- hour delay, $L_{2}(t, d), L_{3}(t, d), L_{4}(t, d) \quad$ are the same coefficients with a one-day, -week and -year's delay, respectively. The root-mean square errors of daily forecast $[1,2]$ do not exceed $4 \%$.

2) Generalized exponential smoothing which can be used for forecasting a total hourly load in the form of:

$$
L(t)=\stackrel{\mathrm{r}_{T}}{\mathrm{u}} \underset{\mathrm{ur}}{f}(t)+\varepsilon(t)
$$

where ${ }^{r_{T}}$ is the exponentially transposed vector of smoothed weights, $\stackrel{\text { u }}{f}(t)$ is the vector of smoothing functions. Smoothing functions are coefficients of the Fourier series for a period of one week.

3) Neural networks and fuzzy logic. A method based on fuzzy logic and neural networks (fuzzy neural networks) is one of the new approaches used to solve the problem of forecasting. The method involves usage of prior information, allows new information to be used for the model development, and the properties of the process modelled to be taken into consideration. This method can use previously known information, lends itself to training, and obvious to a researcher. The main element of a neural network is an artificial neuron, which is a mathematical model of biological nervous cell. An artificial neural network is a set of united and interacting artificial neurons whose operability should be ensured by the procedure of their training. Neural networks are able to detect complex dependencies between the input and output data and make a generalization of existing, but latent properties and relationships. This implies that a trained neural network is able to forecast the future value of a particular sequence based on several previous values or important factors existing at the given moment [3]. This approach to applying the neural networks to the forecasting of electric load does not lose its robustness under the condition of incomplete input information, but requires significant time for their training. Applying the systems with fuzzy logic, i.e. a set of arbitrary nature elements' combination that does not determine clearly their belonging to a certain set, allows us to eliminate the disadvantages of artificial neural networks. Modelling of the energy consumption using fuzzy sets is expedient in the case of studying a too complex technical system or process, as well as in the case of inability to adequately interpret prior information leading to impossibility of applying the accepted quantitative methods.

\section{Essence of an alternative forecasting procedure based on the macromodelling approach}

The development of a mathematical model for energy consumption forecasting takes several stages (Fig. 2). The first stage of the forecasting procedure involves registration, collection, storage and processing of data concerning some real object under research. Data registration is conducted using modern Supervisory Control and Data Acquisition (SCADA) systems, which provide their fixation and storage for a long period of time. The SCADA systems or equivalent automated systems of electric power technical record keeping, which provide quick collection of information and accounting of electrical energy, have been introduced into all power transmission and power supply enterprises of Ukraine.

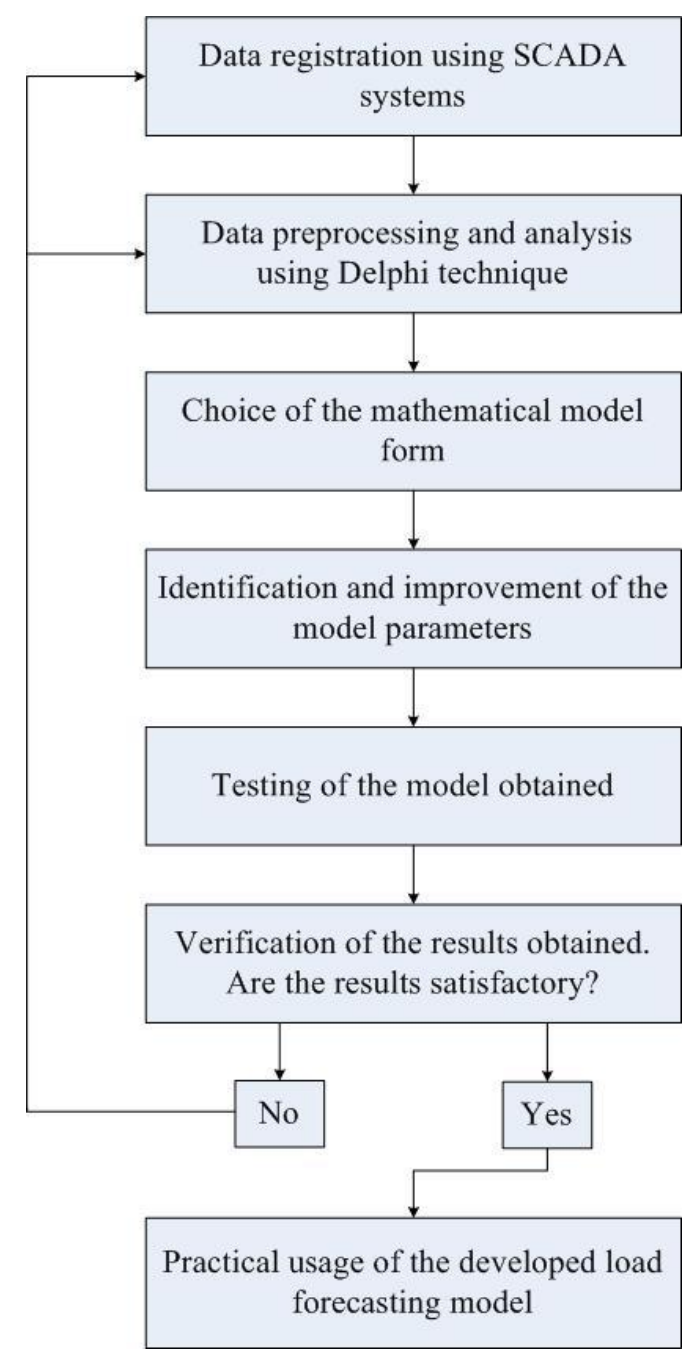

Fig. 2. Algorithm of developing electric load forecasting models.

As a tool intended for monitoring of the power system states, the SCADA complexes allow the data between communication devices and the object to be 
exchanged, and processed in real time. Besides, they ensure keeping the database of technological information and provide emergency messages in an emergency case. From the perspective of data's being used for further mathematical modelling of states or parameters of the electric power systems, such complexes are able to generate reports on the data stored and the progress of technological process, as well as transfer the data and provide connection with external mathematical or special program software - data arrays editors. Data preprocessing involves selection of the period of time for which the forecasting should be carried out, and the period of time for further data verification, as well as its filtering in the case of a considerable amount for the purpose of selecting the model form and simplification of forecasting (Fig. 2). Due to the necessity of analogue signals discretization with the purpose of their registration, computer processing and storage in the form of data arrays, and the necessity of using the available experimental data in the form suitable for the user, it is necessary to develop or use the corresponding mathematical computer science theory.

Therefore, when it is required to select the proper form of mathematical model for the electric load forecasting, mathematical modelling based on discrete autonomous mathematical macromodels using the "black box" technique can become an alternative approach to the solution of this task. The method of mathematical macromodelling is based on the registered characteristics of electric power consumption and representation of its interrelation with the structure of the object under research using homogeneous differential or finitedifference equations in the following form [8]:

$$
\begin{aligned}
& \left\{\begin{array}{l}
\frac{d x}{d t}=\stackrel{r}{d t}(\stackrel{r}{x}) \\
r r \\
y=g(r)
\end{array} ;\right. \\
& \left\{\begin{array}{l}
\underset{x}{x^{(k+1)}}=\stackrel{r}{f}(\underset{x}{r}(k)) \\
\underset{r}{y^{(k+1)}}=\stackrel{r}{g}(\underset{x}{r}(k))
\end{array},\right.
\end{aligned}
$$

where $x^{\prime}$ is the state variables vector, $y$ is the vector of output variables; $f(\cdot), \stackrel{\mathrm{I}}{g}(\cdot)$ are some vectorfunctions.

As the vector of input variables is absent in explicit form when developing a macromodel, let us consider a case when the initial value of the state variables of the modelled object is not equal to zero. The mathematical macromodel will be described mathematically in the form of the following equation:

$$
\left\{\begin{array}{l}
\stackrel{r}{x}_{(k+1)}=\mathbf{F} x^{r}(k)+\Phi\left(\stackrel{r}{x}_{(k)}^{r}, \stackrel{r}{v}^{(k)}\right) \\
y^{r}{ }^{(k+1)}=\mathbf{C} x^{r}(k+1)
\end{array},\right.
$$

where $\mathbf{F}, \mathbf{C}$ are some matrices, and $\Phi\left(\stackrel{r}{x}^{r}(k), r_{v}^{r}(k)\right)$ is the non-linear function of vectors $x$ and ' $v$.

The initial state of the object modelled is described by a zero discrete of the state variables vector ${ }_{x}^{r}(0)$. In this case all components of this vector should be added to the array of unknown coefficients $\lambda^{\prime}$. It should be noted that it is impossible to include the vector $\stackrel{r}{x}^{(0)}$ into the set of the model parameters because each dynamic process will have its own independent value of the vector $r_{x}(0)$. For this fact to be taken into account, it is expedient to divide a vector of unknown coefficients $\lambda^{\prime}$ into two parts. The first part contains coefficients equal for all processes, the second part contains an independent set of elements of vector $\stackrel{r}{x}_{(0)}$ for every process that leads to an increase in unknown quantity of coefficients and complication of the optimization task. Provided the suggested macromodel is used, there is a problem of how to define a zero discrete of the vector $x$ because the components of this vector cannot be measured directly during the natural experiment and should be defined via some element values of the output variables vector $y$. In general case, it means that it is necessary to find some linear or nonlinear dependence of the vector $\stackrel{r}{x}_{(0)}$ on the experimentally measured values of the vector $y$. In particular, while solving the forecasting tasks, this dependence can be developed as a function of several first discretes of output variables:

$$
\underset{x}{r}(0)=\stackrel{r}{f}\left(\stackrel{r}{y}^{(1)}, \stackrel{r}{y}^{(2)}, \ldots, \stackrel{r}{y}^{(l)}\right)
$$

where $l$ is the number of discretes used for searching a zero discrete of the vector $x$.

Optimization is a universal approach [9], which can be used for solution of different tasks while analyzing different mathematical forms; therefore, it can be applied to find additional mathematical dependendencis (4). In fact, it means that elements of the vector ${ }_{x}^{r}(0)$ added to the set of unknown 
coefficients $\lambda^{\prime}$ should be replaced with the coefficients of equation (7), i.e. this equation should be introduced into the macromodel to be developed. If the model has a form of (6), we shall obtain:

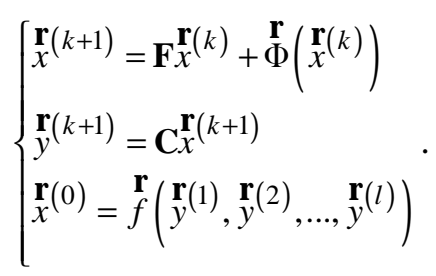

Thus, taking into account the registration features of initial experimental data and the choice of mathematical apparatus used to develope a model of energy consumption, the procedure of developing and verification of an autonomous macromodel of the object under research can be carried out in six stages:

1) Registration of operating characteristics of modes and processes using the SCADA systems, their systematization and storage;

2) Choosing a set of experimental data and a form of the required model, written down using unknown coefficients, that will unsure an accurate description of the modelled object;

3) Choosing independent initial conditions and developing a linear macromodel by the optimization of its coefficients;

4) Addition of a nonlinear function of special form to a linear macromodel;
5) Final optimization of the developed macromodel where all the coefficients are under optimization procedure;

6) Verification of the resulting nonlinear macromodel either as a response to signal data sets, which were used for its development or on an independent set of the experimental data.

At intermediate stages of the macromodel development, it is possible to control its accuracy, whereas with general development of the load forecasting models of different type, the accuracy of the received model is known only when the process of its development has been completed. The optimization approach allows a reduction of the error by adding information that was not contained in the data array used to develop the original macromodel.

\section{An example of developing a mathematical} macromodel for short-term forecasting

Development of discrete macromodels for the load forecasting is a very comfortable approach to the development of mathematical models intended for shortterm prediction because it does not require a prolonged storage of statistical data. In order to verify the efficiency of the approach proposed, we developed a macromodel of daily load forecasting of the power region served by the electric power substation PS Yavoriv-330 kV. To develop an autonomous macromodel of this object, we used the experimental data of 2016. The data of daily power consumption for two weeks of January 2016 is shown in Fig. 3.

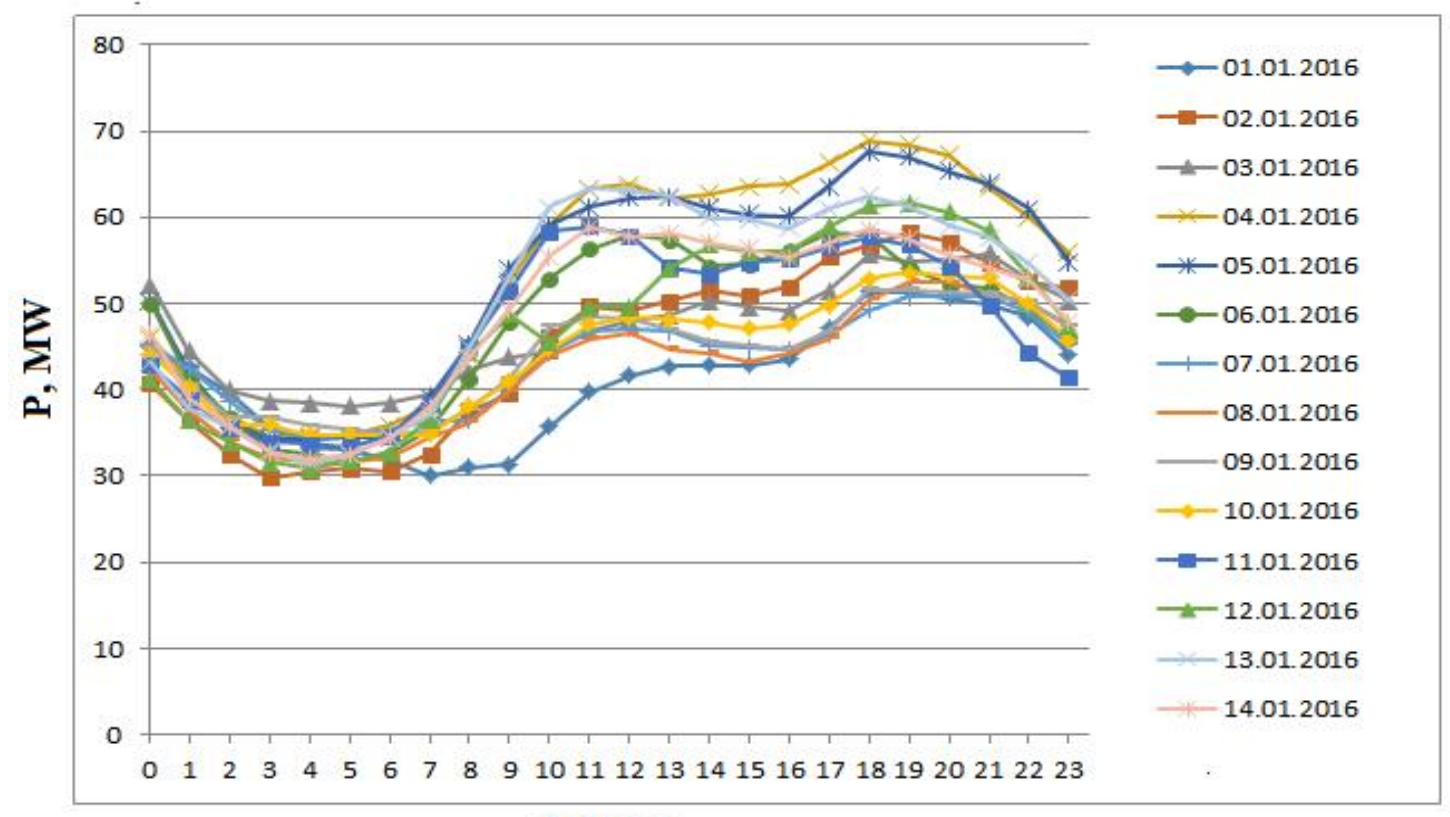

\section{t, hours}

Fig. 3. Daily electric power consumption of substation PS Yavoriv-330, January 2016. 
A discrete macromodel for short-term forecasting of this object is developed in the form of the relationship below:

$$
\left\{\begin{array}{l}
r(i+1)=\mathbf{F} x^{r}(i) \\
y^{r}(i+1)=\mathbf{C} x^{r}(i+1)
\end{array} .\right.
$$

To develop the macromodel, the data of daily power consumption during a one-month's period was used. The initial values of the state variables were defined as a linear dependence on the level of electric power consumption in arbitrary selected periods of time, namely at 11, 16 and 20 o'clock. Hence, relation (7) in our case will be written down as:

$$
\stackrel{r}{x}^{r}(0)=\mathbf{S}\left(\begin{array}{l}
y_{11} \\
y_{16} \\
y_{20}
\end{array}\right) \text {. }
$$

The optimization conducted, as it was expected, found out that accuracy with which the substation under research can be modelled depends on the dimensions of the state variables vector. In particular, for the fourdimensional state variables vector, we succeeded in obtaining an adequate macromodel.

For perception convenience, the coefficients of the macromodel obtained are written down in banded form. So, we can see that coefficients of the matrices are as follows:

a) matrix $\mathbf{F}$ :

$\mathbf{F}=[1.087,-0.334,0.378,-0.402,0.135,1.065,0.303$, $-0.034,-0.162,0.180,0.937,0.328,0.399,0.234,0.709$, $1.062]$

b) matrix $\mathbf{C}$

$\mathbf{C}=[-0.656,0.397,0.036,-0.472]$;

c) matrix $\mathbf{S}$

$\mathbf{S}=[-0.130,0 .-0.649,0.344,0.082,0.083,0.504,0.206$, $-0.342,-0.099,-0.307,-0.069]$;

Response of the developed mathematical macromodel to the input data during two arbitrary selected days from the monthly data array of January 2016 used for its development is shown in Fig. $4(a, b)$, where curve (1) is a chart of the daily power consumption used for the macromodel design, curve (2) - is a response of the developed macromodel.

The verification of the obtained autonomous macromodel was carried out using an independent set of data. For this purpose, the results of electric power consumption during February 2016 were used.

The verification results for the arbitrary selected day from the monthly data array of February 2016 are shown in Fig. 5, where curve (1) is a chart of independent daily power consumption not used for the macromodel design, curve (2) - is a response of the designed macromodel.

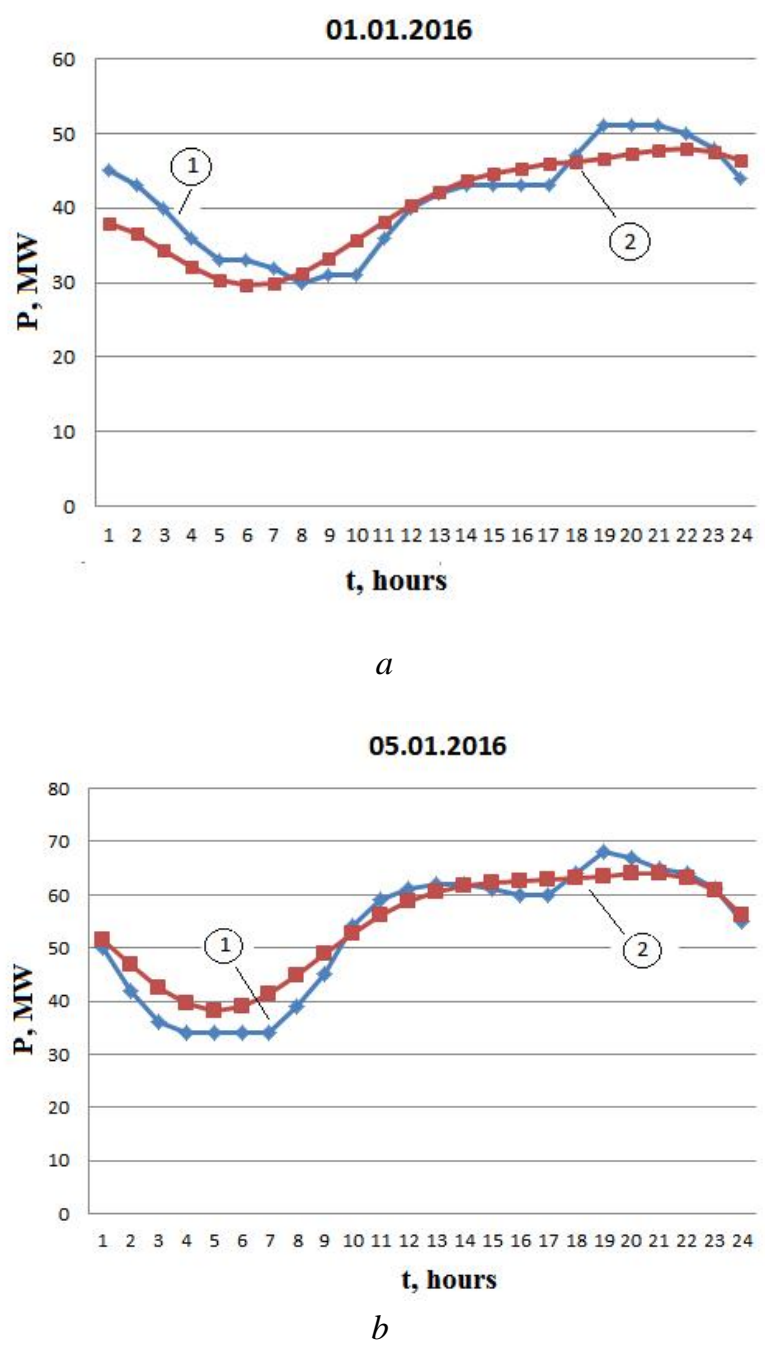

Fig. 4. Input data and respond of the load forecasting macromodel, January 2016.

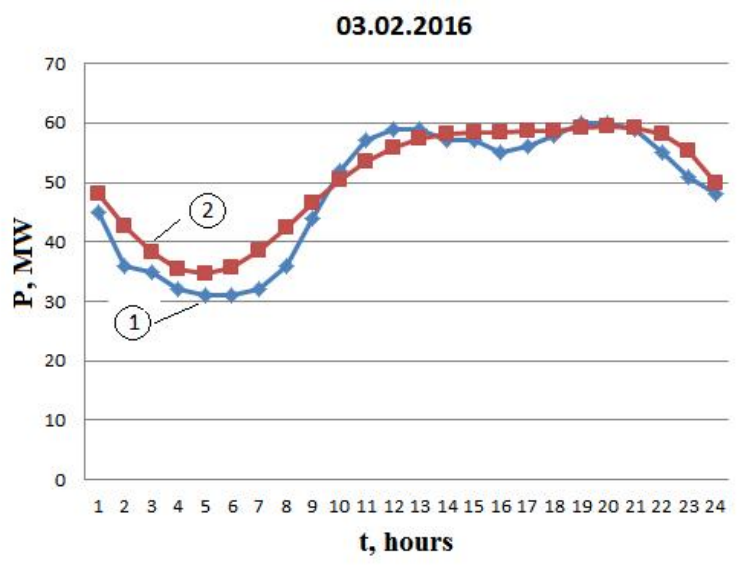

Fig. 5. Input data used for verification of a load forecasting macromodel, February 2016. 


\section{Conclusions}

Based on the derived results, it is possible to make a conclusion that the presented approach of autonomous macromodelling can be used for developing mathematical models intended for the forecasting of electric power consumption with sufficiently high level of adequacy. The proposed approach allows us to develop deterministic mathematical models of power consumption and avoid both the procedure of filtration of astronomic and random factors inherent to the models of other types and the necessity to describe dynamic processes by static models.

\section{References}

[1] D. Bunn and E. Farmer, Comparative Models for Electric Load Forecasting, New York, USA: Willey, 1985.

[2] H. Alfares and M. Nazeeruddin, Electric load forecasting: literature survey and classification of methods, International Journal of Systems Science, vol. 33, pp. 23-34, 2002.

[3] H. Hippert, C. Pedreira, and R. Souza, "Neural networks for short-term load forecasting: a review and evaluation", IEEE Transactions on Power Systems, vol. 16, no. 1, pp. 44-55, 2001.

[4] Yu. Varestsky, T. Nakonechnyy, M. Fedoniuk, and V. Komar, "Architecture of itelligent monitoring system of power network nonsinusoidal modes", Naukovi pratsi Vinnytskogo natsionalnoho tekhnichnoho universytetu, no. 1, pp. 1-10, Vinnytsia, Ukraine, 2010. (Ukrainian)

[5] P. Chernenko and O. Martynyuk, "Enhancing the Effectiveness of Short-Term Forecasting of Electric Load of United Power System", Tekhnichna elektrodynamika, no. 1, pp. 63-70, Kyiv, Ukraine: Institute of Electrodynamics of Ukraine, 2012.

[6] A. Singh, S. Ibraheem, and M. Muazzam, "An Overview of Electricity Demand Forecasting Techniques", Network and Complex Systems, vol. 3, no. 3, pp. 38-48, 2013.

[7] S. Soliman and A. Al-Kandan, Electrical load forecasting: modeling and model construction, Oxford, UK: Butterworth-Heinemann, 2010.

[8] P. Stakhiv, Y. Kozak, and O. Hoholyuk, "Effectiveness Evaluation of Discrete Macromodelling to Forecast Power Consumption of Electric Power Systems Component Elements, Computational problems of electrical engineering, vol. 6, no. 1, pp. 45-48, 2016.

[9] Yu. Kozak, "Modification of the Rastrigin's director cone method". In Elektronika $i$ sviaz: Problemy fizicheskoy i biomeditsinskoy elektroniki, p. 424, 1997. (Ukrainian)

\section{МАКРОМОДЕЛЮВАННЯ ЯК ЗАСІБ КОРОТКОТЕРМІНОВОГО ПРОГНОЗУВАННЯ ЕНЕРГОСПОЖИВАННЯ ОБ'ЄКТІВ ЕЛЕКТРОЕНЕРГЕТИЧНИХ СИСТЕМ}

Оксана Гоголюк, Юрій Козак, Тарас Наконечний, Петро Стахів

Розглянуто методи побудови моделей енергоспоживання та описано альтернативний метод прогнозування енергоспоживання визначених об'єктів 3 використанням дискретних макромоделей, який дає змогу оцінювати кількісні характеристики споживання електричної енергії у майбутньому, використовуючи відомі дані натурного експерименту. Описано особливості отримання експериментальних даних та процедуру побудови дискретних автономних макромоделей на їхній основі у вигляді “чорної скриньки” у формі змінних стану. Запропоновано спосіб вибору вектора початкових змінних стану та спосіб його введення у макромодель у зв'язку з відсутністю вектора вхідних змінних у явному вигляді. Обгрунтовано доцільність застосування дискретних автономних макромоделей для короткотермінового енергоспоживання. Наведено отриману макромодель конкретного об'єкта енергоспоживання для короткотермінового прогнозування електричного навантаження та виконано верифікацію отриманих результатів.

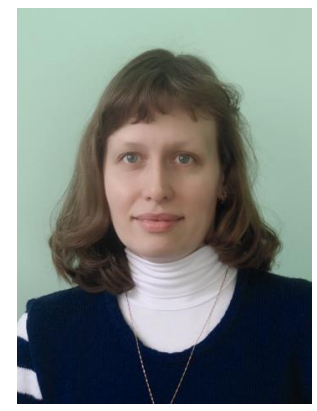

Oksana Hoholyuk - Ph.D., Ass. Professor graduated from Department of Physics of Ivan Franko State University of Lviv, Ukraine. She received her Ph.D. degree in the field of theoretical electrical engineering. Since 2004 she has been working at the Department of Theoretical Electrical Engineering at Lviv Polytechnic National University, Ukraine. Her scientific interests are focused on mathematical modelling of electric circuits and systems.

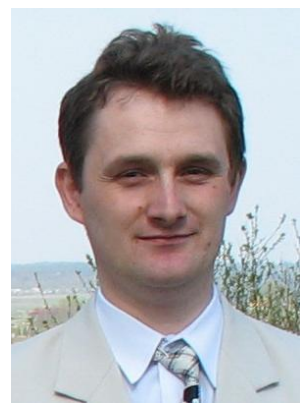

Yuriy Kozak - Ph.D., graduated from Department of Physics of Ivan Franko State University of Lviv, Ukraine, and received his Ph.D. degree in theoretical electrical engineering. His research work is devoted to the development of mathematical models of electrical system components. His scientific interests are focused on mathematical modelling of dynamic processes in electrical systems, numerical methods, methods of optimization and parallel programming. 


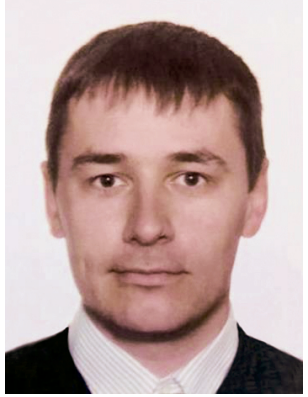

Taras Nakonechnyy graduated from the Institute of Electric Power Engineering and Control Systems of Lviv Polytechnic National University, Ukraine. He received his Ph.D. degree in the field of electric power engineering. His main imterests are connected with electrical stations, networks and systems. Now he is working at the National Company

"Ukrgenergo". His scientific interests are focused on the development of intellectual monitoring systems of nonsinusoidal regimes of electric power networks and the ensuring of electric power quality in power supply systems.

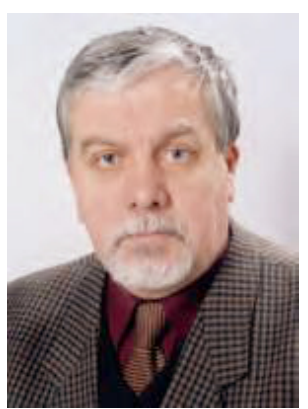

Petro Stakhiv - Ph.D., D.Sc., Professor, graduated from Department of Physics of Lviv State University, Ukraine, and received the M.Sc. degree in radiophysics and electronics. In 1975 he received a Ph.D. degree in theoretical electrical engineering and in 1992 he received a D.Sc. degree in the same specialty. Since 1996 he has been working at Lviv Polytechnic National

University as Head of Department of Theoretical and General Electrical Engineering. His scientific interests are mainly concerned with mathematical modelling and simulation of dynamic processes in electrical systems, numerical methods, optimization methods, system theory, and parallel programming. 